\title{
Research on the impact of informal environmental regulation on investment of environmental pollution -- Based on the perspective of public supervision
}

\author{
Zhang Yuxin ${ }^{1, a}$, Sun Chenghao ${ }^{2, b^{*}}$ \\ ${ }^{1}$ Law School, Shandong University, Qingdao, Shandong, China \\ ${ }^{2}$ School of Economics and Trade, Shandong Management University, Jinan, Shandong, China
}

\begin{abstract}
Based on provincial data from 2010 to 2015, this paper uses regression model to analyze the impact of informal environmental regulation on investment of environmental pollution. The regression result shows that informal environmental regulation can significantly promote environmental investment of environmental pollution. Therefore, it is necessary to improve the mechanism of citizens' environmental participation and strengthen environmental relative investment, ultimately promoting high-quality development.
\end{abstract}

\section{Introduction}

In recent years, with the rapid development of Chinese economy, the problem of environmental pollution has become increasingly prominent. As a special public good, it is difficult to solve the problem of free rider only by relying on the market mechanism for environmental pollution control, which needs to be combined with regulatory means to improve the effect. According to the existing research classification, environmental regulation can be divided into formal environmental regulation led by the government and informal environmental regulation relying on the participation of the public and social organizations. It is undeniable that formal environmental regulation plays an important role in promoting environmental governance, but it has some limitations, which leads to the policy implementation effect not been fully played. For instance, the cost of formal environmental regulation is high, and the phenomenon of incomplete implementation is common. Therefore, as an important supplement to environmental regulation, informal environmental regulation based on public participation and supervision emerges at the historic moment. In order to encourage the public participation in environmental protection supervision in accordance with the law, the Law on Public Participation in Environmental Protection issued in 2015, which stipulates that citizens can participate in supervision by means of reporting and letters, and clarifies the legal status of public participation. For instance, In 2018, the "12369" environmental Wechat reporting platform of the Ministry of Environmental Protection received 710,117 reports from the public. On the other hand, with the improvement of national attention to environmental protection, the national investment in environmental governance increased from 761.219 billion yuan in 2010 to 880.63 billion yuan in 2015 , with the overall scale continuously increasing. Previous studies have shown that the behavior of government and enterprises may be affected by public supervision. Then, in the context of Chinese widespread concern about pollution control and environmental supervision, can informal environmental regulation represented by public supervision effectively promote investment in environmental governance? Exploring the above issues is of great significance to further clarify the impact path of environmental regulation and promote high-quality economic development.

Since the concept of non-environmental regulation was first proposed by Pargal and Wheeler (2017), scholars have carried out research from the perspectives of legal rights and economic impact ${ }^{[1]}$. Jiang (2015) put forward the approach of public participation in environmental protection from the aspects of plan participation, process participation, terminal participation and behavior participation ${ }^{[2]}$. $\mathrm{Fu}(2016)$ combined with the latest development status in the era of big data, believes that the current environmental information governance is in the period of transformation from environmental information disclosure to environmental information public service, and its goal path focuses on improving public satisfaction, optimizing environmental information disclosure,strictly integrating environmental information resources and realizing multiple supply ${ }^{[3]}$. In recent years, some scholars gradually began to pay attention to the economic impact of non-environmental regulations. Luo (2020) used CSS2013 data to discuss the impact of environmental information disclosure on residents'willingness to participate in environmental governance. The results showed that government environmental information disclosure significantly

* Corresponding author: ${ }^{\mathrm{b}}$ sunch2015@163.com

azyx.9012@163.com 
promoted residents' willingness to participate in environmental governance by enhancing residents' environmental cognition and government information ${ }^{[4]}$. Cao (2011) suggests that the environmental mass incidentscan promote the central government's environmental supervision and polical adjustment on local governments ${ }^{[5]}$. Kathuria (2007) believes that informal environmental regulation mainly refers to the expression of public's appeal for the improvement of environmental quality through complaints, petition letters, assemblies and processions. Compared with formal environmental regulation, informal environmental regulation is conducive to reducing information asymmetry ${ }^{[6]}$. Based on the data of 85 townships in China, Hua (2002) found that the environmental performance pressure of the superior government and the public complaints within the jurisdiction would force the local government to strengthen environmental regulation and improve environmental services ${ }^{[7]}$. Using provincial panel data from 2003 to 2011, Yu (2014) found that public participation in environmental protection would encourage local governments to take more environmental protection measures, which would help promote environmental governance. Most studies have explored the path and effect of informal environmental regulation on environmental governance from the perspective of environmental governance ${ }^{[8]}$. However, few of them have focused on the effect of public supervision on investment of environmental pollution. Therefore, this paper uses Chinese provincial panel data from 2010 to 2015 to study the impact of informal environmental regulation on investment of environmental pollution, so as to provide a basis for clarifying the role of informal environmental regulation and promoting high-quality development.

\section{Materials and Methods}

\subsection{Variable selection}

\subsubsection{Main dependent variable: investment of environmental pollution}

This paper uses theinvestment of environmental pollution in China Environmental Statistical Yearbook as the explained variable. According to the statistical caliber of China Environment Yearbook, the investment in environmental pollution control is the sum of the investment in urban environmental infrastructure construction, the investment in industrial pollution source control and the investment in environmental protection projects completed in that year.In order to avoid heteroscedasticity, the index is logarithmized in this paper.

\subsubsection{Main explanatory variable: public environment al supervision (Reg)}

There are many methods to construct informal environmental regulation index in the existing literature, and there are great differences among different methods. In order to reflect the degree of public environmental supervision, this paper selects two variables, the number of letters and the number of visits to represent the degree of public supervision in informal environmental regulation. In order to avoid heteroscedasticity, the index is also logarithmized in this paper.

\subsubsection{Control variables}

Referring to the existing research, this paper selects the ratio of industrial structure bias (stru), the proportion of foreign direct investment (fdi), the proportion of local financial investment (fis) as the control variables. The construction method of relevant variables is shown in the following Table 1

Table 1 Selection and description of variables

\begin{tabular}{|c|c|c|}
\hline Variable name & Symbol & Description \\
\hline $\begin{array}{c}\text { The ratio of } \\
\text { industrial } \\
\text { structure bias }\end{array}$ & stru & $\begin{array}{c}\text { Added value of secondary } \\
\text { industry/regional GDP }\end{array}$ \\
\hline $\begin{array}{c}\text { Proportion of } \\
\text { foreign direct } \\
\text { investment }\end{array}$ & fdi & $\begin{array}{c}\text { Amount of foreign direct } \\
\text { investment in that } \\
\text { year/regional GDP in that } \\
\text { year }\end{array}$ \\
\hline $\begin{array}{c}\text { Proportion of } \\
\text { local financial } \\
\text { investment }\end{array}$ & fis & $\begin{array}{c}\text { Local financial investment } \\
\text { in that year/regional GDP } \\
\text { in that year }\end{array}$ \\
\hline
\end{tabular}

\subsection{Data sources and description}

Based on the availability and continuity of data, the sample interval selected in this paper is the interprovincial panel data from 2010 to 2015 . The descriptive statistics of various variables are shown in Table 2 below. All data are derived from China Statistical Yearbook, China Environmental Statistics Yearbook and Wind data platform.

Table 2 Descriptive statistics

\begin{tabular}{|c|c|c|c|c|}
\hline Variable & Mean & $\begin{array}{c}\text { Minimu } \\
\text { m value }\end{array}$ & $\begin{array}{c}\text { Maximu } \\
\text { m value }\end{array}$ & $\begin{array}{c}\text { Standard } \\
\text { deviation }\end{array}$ \\
\hline $\begin{array}{c}\text { Investment } \\
\text { in } \\
\text { environmen } \\
\text { tal } \\
\text { governance }\end{array}$ & 5.28 & 2.83 & 7.26 & 0.83 \\
\hline $\begin{array}{c}\text { Regional } \\
\text { environmen } \\
\text { tal visits }\end{array}$ & 6.92 & 3.30 & 8.83 & 1.12 \\
\hline $\begin{array}{c}\text { Regional } \\
\text { Environmen } \\
\text { tal Letters } \\
\text { and } \\
\text { Complaints }\end{array}$ & 8.14 & 4.70 & 11.66 & 1.29 \\
\hline $\begin{array}{c}\text { Industrial } \\
\text { structure } \\
\text { bias }\end{array}$ & 0.40 & 0.13 & 0.53 & 0.08 \\
\hline
\end{tabular}




\begin{tabular}{|c|c|c|c|c|}
\hline $\begin{array}{c}\text { Proportion } \\
\text { of foreign } \\
\text { direct } \\
\text { investment }\end{array}$ & 0.02 & 0.01 & 0.12 & 0.02 \\
\hline $\begin{array}{c}\text { Proportion } \\
\text { of local } \\
\text { financial } \\
\text { investment }\end{array}$ & 0.26 & 0.11 & 0.76 & 0.12 \\
\hline
\end{tabular}

\section{Results \& Discussion}

In order to explore the impact of informal environmental regulation on investment of environmental pollution, this paper constructs the following regression model:

$$
I n v_{i t}=\beta_{0}+\beta_{1} \operatorname{Reg}_{\mathrm{it}}+\beta X_{i t}+u_{i t}
$$

Where, Inv $v_{i t}$ represents investment of environmental pollution, $\operatorname{Reg}_{\text {it }}$ is public environmental supervision,

$X_{i t}$ represents control variables such as economic development level, and $u_{i t}$ is the error term. In order to overcome the influence of endogeneity, this paper uses fixed effect panel model to estimate and uses robust standard error method to correct. As shown in Table 3, the regression results show that informal environmental regulations such as public supervision can significantly promote investment of environmental pollution. Specifically, the number of regional environmental visits and letters can enhance the investment in environmental pollution control. According to the regression results of other control variables, the proportion of fiscal expenditure can improve regional investment of environmental pollution, because the important source of investment of environmental pollution is local financial funds, while other variables have no significant effect.

Table 3 Main regression results

\begin{tabular}{|c|c|c|}
\hline & $(1)$ & $(2)$ \\
\hline $\begin{array}{c}\text { Number of visiting } \\
\text { complaints }\end{array}$ & $0.189^{* *}$ & \\
\hline $\begin{array}{c}\text { Number of letters and } \\
\text { complaints }\end{array}$ & $(0.076)$ & $0.145^{* * *}$ \\
\hline $\begin{array}{c}\text { Proportion of foreign direct } \\
\text { investment }\end{array}$ & 1.728 & $(0.048)$ \\
\hline $\begin{array}{c}\text { Proportion of fiscal } \\
\text { expenditure }\end{array}$ & $(3.141)$ & $(3.088)$ \\
\hline $\begin{array}{c}\text { The ratio of Industrial } \\
\text { structure bias }\end{array}$ & $(1.439)$ & $2.660^{*}$ \\
\hline & -1.680 & -1.524 \\
\hline Constant & $(1.251)$ & $(1.148)$ \\
\hline Observations & $(0.584)$ & $(0.836)$ \\
\hline R-squared & 0.171 & 0.127 \\
\hline
\end{tabular}

Note: ***,**,* represent significant at $1 \%, 5 \%$, and $10 \%$, respectively.

In addition, in order to solve the endogenous problems, this paper take robustness test. There are two reasons for the endogenous problems in the above regression equation. First, there may be variables that can affect investment of environmental pollution and are not related to other explanatory variables, which will lead to the omission of variables. Second, the increase of public supervision leads to increased investment in local environmental governance, but increased governance investment may in turn reduces public supervision, which can lead to reverse causality. In order to overcome the above problems, this paper adopts two methods to adjust. First of all, since the current investment level of environmental governance may be affected by the intensity of public supervision in the previous period, this paper makes a regression of the public supervision level after one period lag. In addition, this paper selects the amount of local environmental administrative punishment as an instrumental variable for regression, because there is a close relationship between the amount of local environmental administrative punishment and the number of public complaints, while the amount of punishment has little relationship with other control variables. Table 4 reports the test results of instrumental variables, which show a strong correlation and no obvious relationship with other influencing factors of household consumption, which is consistent with the relevant assumptions. Table 5 reports the regression results of using instrumental variables and lagging one period, and the results remain unchanged, which further verifies the previous conclusion that informal environmental regulation can significantly promote the investment of environmental pollution.

Table 4 Test results of instrumental variables

\begin{tabular}{|c|c|c|}
\hline $\begin{array}{c}\text { Inspection } \\
\text { content }\end{array}$ & Inspection index & Test results \\
\hline $\begin{array}{c}\text { Unidentifiable } \\
\text { inspection of } \\
\text { instrumental } \\
\text { variables }\end{array}$ & $\begin{array}{c}\text { Kleibergen-Paap } \\
\text { LM Inspection }\end{array}$ & Significant \\
\hline $\begin{array}{c}\text { Weak } \\
\text { instrumental } \\
\text { variable } \\
\text { inspection }\end{array}$ & Wald F Inspection & Significant \\
\hline $\begin{array}{c}\text { Exogenous } \\
\text { inspection of } \\
\text { instrumental } \\
\text { variables }\end{array}$ & C-statistics & Significant \\
\hline
\end{tabular}

Table 5 Robustness test

\begin{tabular}{|c|c|c|}
\hline & $(1)$ & $(2)$ \\
\hline $\begin{array}{c}\text { Case number of } \\
\text { environmental punishment }\end{array}$ & $0.405^{* *}$ & \\
\hline & $(0.190)$ & $0.164^{* * *}$ \\
\hline $\begin{array}{c}\text { Number of visiting } \\
\text { complaints (lagging one } \\
\text { period) }\end{array}$ & & $(0.032)$ \\
\hline & \multicolumn{2}{|c|}{ Controlled } \\
\hline Control variables & $2.493^{* * *}$ & $3.841^{* * *}$ \\
\hline Constant & $(0.483)$ & $(0.476)$ \\
\hline & 180 & 150 \\
\hline Observations & 0.124 & 0.232 \\
\hline R-squared & \multicolumn{2}{|c}{}
\end{tabular}




\section{Conclusions}

Based on the statistical yearbook data, this paper discusses the relationship between informal environmental regulation and investment of environmental pollution from the perspective of public supervision. The overall regression results show that informal environmental regulation can significantly promote investment of environmental pollution, and the results of robustness test further prove the above conclusions. According to the results of heterogeneity regression, informal environmental regulation has a more obvious promoting effect on the eastern region. The following policy recommendations are proposed.

First, attention should be paid to the bottom-up demand for environmental participation at the public level. Local governments should further strengthen publicity on environmental protection, improve information disclosure mechanisms, establish effective mechanisms for environmental complaints and supervision, fully mobilize the enthusiasm of public for environmental supervision, and promote the effective improvement of environmental conditions.

Second, the government should further improve the mechanism of citizens' environmental participation on the basis of the relevant laws and regulations that have been issued. Policy formulation should give full consideration to the public demands, expand the scope and channels of citizens' environmental participation, and encourage citizens to safeguard the right to environmental protection through public interest litigation.

Third, attention should be paid to investment in regional environmental governance. Therefore, the government should actively guide the adjustment of governance investment structure, properly control the proportion of investment in urban environmental infrastructure construction, increase the proportion of investment in industrial pollution control and formulate appropriate environmental investment strategies according to regional differences.

\section{Acknowledgments}

This paper was supported by Sailing Project of Shandong Management University (QH2020R06)

\section{References}

1. Pargal.S., Mani.M., Huq.M.(1997) Inspections and emissions in India: puzzling survey evidence about industrial pollution. NBER Working paper., https:// ssrn.com $/$ abstract $=620557$

2. Jiang, J.P., Yuan, X.(2005) The idea of building publ ic participation mechanism in environmental protect ion. Journal of Jiangxi University of Finance and ec onomics., 05: 14-15+21.

3. Fu, Y.M.(2016) Environment information governanc e reform in the era of big data: from information dis closure to public service. Chinese Environmental M anagement., 04: 48-51.

4. Luo, K.Y.,Tian.Q.B.(2020) Environment Informatio n Disclosure and Residents' Willingness to Participa te in Environmental Governance. Discussion on Mo dern Economy., 07: 33-43.

5. Cao, Z.(2011) The Vertically Decentralized Authorit arianism and the Mechanisms of Political Stability i n China. Sociological Studies., 25: 1-40.

6. Kathuria, V. (2007) Informal regulation of pollution in a developing country: evidence from India. Ecolo gical Economics.,63:403-417.

7. Hua, W., Di, W.(2002) The determinants of governm ent environmental performance-an empirical analysi s of Chinese townships. Policy Research Working P aper Series., 704-708.

8. Yu, W.C., Gao, N., Gong, Q.(2014) Public Demands, Local Officials' Incentive and Environmental Gove rnance. Zhejiang Social Sciences.,05:23-35+10+ 15 6-157. 